\title{
Higher Education Service Quality based on Students' Satisfaction in People's Republic of China
}

\author{
Abdul Ghaffar Mastoi ${ }^{1 *}$ Lu XinHai ${ }^{1}$ Wimonsiri Saengkrod ${ }^{2}$ \\ 1. College of Public Administration, Huazhong University of Science and Technology, Wuhan, Hubei, \\ China \\ 2. College of Local Administration (COLA), Khon Kaen University, Khon Kaen, Thailand
}

\begin{abstract}
The quality of education is an important factor that is considered for attracting and retaining the students as it is a substantial investment made by their parents. Most of the recent studies of service quality in education are focusing on higher education as more universities and colleges clamor and compete for gaining some ranking and accreditation in their programs and institution. Hence, in the quest for internationalization of quality in education, assurance of service quality becomes the dire need and eventually taking center stage. Service quality enhances a university's image. Hence, delivering quality service has become an important goal for most higher education institutions (HEIs) and for distinguishing it among other common competitors. This is a case study of China for evaluating the service quality of higher education institutions based on students' satisfaction. This study is based on data collected from 500 questionnaires and analyzed through SPSS. By using multiple linear regression analysis, it showed us which factor is playing how much role in the prediction of students ${ }^{\text {ee }}$ satisfaction. This study has revealed some significant findings and showed that there is a positive relationship between most of the determinants of higher education quality and students' satisfaction. As student's satisfaction has been positively associated with their performance in university as well as later in their workplaces therefore it is detrimental that this aspect of university student's dependence on the service quality provided by higher education institutions can be ignored as it eventually affects the productivity of the workforce of a society and eventually economy of a nation.
\end{abstract}

Keywords: Student Satisfaction, Service Quality, Higher Education. P. R. China

DOI: $10.7176 / \mathrm{JEP} / 10-6-15$

\section{Introduction}

Higher education has turned into a competitive enterprise among both private and public higher education institutions (HEIs). In view of the increasing competition in higher education industry, various public and private colleges and universities are facing the challenge of declining student enrollment, poor strategic marketing planning, intense competition between other college or universities that offer the same courses and better service quality found wanting. The quality of education is an important factor that is considered for attracting and retaining the students as it is a substantial investment made by their parents. Most of the recent studies of service quality in education are focusing on higher education as more universities and colleges clamor and compete for gaining some ranking and accreditation in their programs and institution (Sultan and Ho, 2012). Hence, in the quest for internationalization of quality in education, assurance of service quality becomes the dire need and eventually taking center stage. Service quality enhances a university's image. Hence, delivering quality service has become an important goal for most higher education institutions (HEIs) and for distinguishing it among other common competitors.

The perceived quality of higher education institutions for students today is rapidly changing rapidly especially with the introduction of new technologies, skills, techniques and knowledge required in the different fields of their studies. The most visible change for the education institutions to cater to is the need for these institution for knowing their customer needs from different groups of students and different program requirements as most students from every intake can have differed needs and expectations. Lack of quality assurance measures has also been seen for assessing student satisfaction towards services as regular quality assurance of services keep influencing the perception of the students towards their knowledge and their ability to build the student trust. This lack of quality assurance during and in their marketing approaches and services could turn out be the biggest hindrance for the higher institutions in competing with other institutions. This is a study conducted in China in terms of evaluating the service quality of higher education institutions based on students' satisfaction. 


\subsection{Historical Perspective on China's Higher Education}

An emergence of modern China and Chinese Cultural Revolution has been associated with year 1977 when Deng Xiaoping, the Chinese Premier, along with other things made the decision of resuming the National Higher Education Entrance Examination (Gao Kao), which had a profound impact on Chinese higher education in history. From 1980s, Chinese higher education went through a series of reforms that slowly and gradually brought about improvement in Chinese higher education institutions. Structural reform consisted of five parts, namely reforms in provision of higher education, higher education finance, higher education governance, recruitment and job-placement and inner-institution administration, which was the most difficult to be implemented. Aims and objectives of all these reforms were providing higher education institutions increased autonomy and the ability for better meeting the needs of students, so that the state can focus exclusively on macro planning. Since the late 1990s, Chinese higher education experienced rapid development benefits of which are being availed by the modern China (National Bureau of Statistics of China). In 2012, China had postsecondary education enrollments of over 31 million in total, which included 25.6 million in regular higher education sector and nearly six million in the adult higher education sector. 1.7 million (5.5\%) were enrolled at the graduate level, 16.7 million (53.2\%) were pursuing bachelor degrees, and the rest 13 million (41.3\%) was enrolled in two- or three-year programs. China already surpassed the United States in in terms of enrollments in higher education and has the largest higher education system in the world now. In recent years, China has also become a favorite and major destination for international students. There were 157,845 international students enrolled in Chinese colleges and universities in 2012, and 18,259 of these international students graduated and received academic degrees. As of 2013, China deemed to be the most popular country in Asia for international students, and was ranked third overall among all other countries (Pan and Xiao, 2008).

\subsection{Statement of the Problem}

Chinese development especially since Cultural Revolution is an indirect result of its prompt attention towards higher education. China seems to be leading in the education industry today but still lacks various instruments of quality in its higher education and is behind major other developed countries like USA, IK, Australia and Canada in terms of quality of education provided to its students. This study is an attempt to give an overview of quality of higher education in China based on students' satisfaction and the few sectors it needs to cater its full attention towards for improving quality of higher education.

\subsection{Objective of the Study}

Main objective of this study is to find out the overall quality of higher education through students' satisfaction in a cross-sectional study in China.

\section{Specific objectives}

- To assess satisfaction level of students with administrative quality of the university.

- To assess students' satisfaction level with physical environment quality of the university

- To assess satisfaction level of students with core educational quality of the university.

- To assess satisfaction level of students with support facilities quality of the university.

- To assess satisfaction level of students with transformative quality of the university.

- To assess overall satisfaction level of Chinese students in universities.

\section{Literature Review \\ 2.1 Service Quality}

Service quality is commonly used the most critical prerequisite to establish and sustain satisfying relationship with valued customers. Many organizations tend to emphasize on service quality due to their strategic role in enhancing competitiveness especially in the context of attracting new customers and enhancing relationship with existing client (Ugboma, et al, 2007). According to Malik, et al,(2010), the quality service in service educational institutions is a significant factor considered to attract and retain the students in particular and other stakeholder/customer in general. Retaining service quality in higher education institutions is not only associated with its significance rather it is also considered a basic ingredient to achieve excellence in higher education. It was also explored that universities must realize the education service and other services that universities offer must be considered alike business like various other service industries and universities must start focusing on student's, academic staff's and all other stakeholders' performance and wellbeing while they deliver the service (Malik et al., 2010; Mulu, 2012). Most of the researchers in the service-marketing field argue that a distinctive approach to define and measure service quality is in dire need due to the distinctive characteristics of services. A service-marketing definition of quality revolves around the idea that quality is supposed to be judged on the basis of the assessment of the user or consumer of the service. This eventually turns out to be the most common definition of service quality as it is considered as the measure of how well the service level delivered matches customer expectations (Gronroos, 1984; Parasuraman et al., 1985). However, other researchers have other views and they argue that service quality must be derived from perceptions of performance alone (Cronin and Taylor, 1992). This presents a significant weakness of the research that has been conducted to date in the marketing 
literature; there has been disagreement on the existence of a consensus regarding the best way for defining and measuring service quality. In addition, no single model of service quality has been widely accepted by all the researcher around the globe. However, Gronroos' (1984) and Parasuraman et al.'s (1985) conceptual frameworks are widely cited and to some extent introduce ideas to be applied in the higher education context.

Service Quality plays an important role in the existence of an organization (La and Kandampully, 2004). The better image in the mind of consumers, their trust whether they can rely on the organization and their future usage intentions are all result of service quality. Therefore, previous studies have already discussed the significance of customer's opinion and service quality in detail (Carrillat, et al., 2007; Samat, et al., 2006; Awan, et al., 2008). The continuous struggle for measuring the service quality has resulted in the creation of many service quality measurement models. Some models are validated due to realization of certain conceptualized dimensions in the environment, while others empirically show the importance of these dimensions to the service quality (Abdullah 2005, 2006a).

\subsection{Universities as Service Providers}

Quality is relative to the client of the term and the circumstances in which it is included. It implies distinctive things to distinctive individuals; without a doubt the same individual may embrace distinctive conceptualizations at diverse minutes. This raises the issue of whose quality? (Harvey and Green, 1993). There are a variety of partners in higher education, students, managers, educating and non-teaching staff, government and its different kinds of funding agencies, accreditors, validators, evaluators, and assessors (also including proficient bodies) (Burrows and Harvey, 1992). Each of these partners incorporate a distinctive view on quality, impacting their own interests in higher instruction. For illustration, to the committed researcher the quality of higher instruction is its capacity to deliver a unfaltering stream of individuals with tall intelligence and commitment to learning that will proceed the method of transmission and advancement of information. To the government a better quality framework is one that produces prepared researchers, engineers, planners, specialists and so on in numbers judged to be required by society. To an industrialist a better quality instructive institution may be one that turns out graduates with wide-ranging, adaptable minds, promptly being able to secure abilities, and adjust to modern strategies and needs (Reynolds, 1990). Barnett (1994) outlines this interconnecting between conceptions, approaches and results within the setting of four prevailing modern conceptions of higher education. When higher education is conceived as the generation of exceedingly qualified labor, the graduates are seen as items whose career profit and work will relate to the quality of the education that they have gotten.

The focus mostly rests on the participation rate or percentage growth of students from under-privileged backgrounds, including that of mature students, part-time students and disabled students when the higher education is being conceived as a matter of increasing life chances. Barnett (1994) contrasts above conceptions of higher education in terms of extending life chances for students with another set of conceptions of university education which focus mostly on increasing the quality of the student experience in educational environment. Barnet's conceptions include exposing students, or letting them into the process and experience for pursuing further education and knowledge, increased development of students' autonomy and integrity, better cultivate the general intellectual abilities of all the students for forming perspectives and vision which are beyond the borders of a single discipline and cultivation and development of critical reason in university students. As Rowley (1997) states: While the quest for service quality dimensions has an attractive simplicity, it is important to recognize that this is but a part of the complex jigsaw associated with managing and measuring service quality in higher education. Wiers-Jenssen et al. (2002), also highlights the complexity of the concept in the higher education context in recent studies. Although there is a dominant paradigm existing with respect to the definition of quality focused on the consumer within the service quality literature, (Grapentine, 1999; Robinson, 1999). This is not the true in the literature about educational quality. Harvey and Green (1993) state there is 'no single correct definition of quality', but rather quality should be seen as a 'stakeholder-relative' concept. Tam (2001) more recently has discussion on the more contested views over quality and how it must be measured in higher education.

Three contrasting approaches to the measurement of quality in education can be identified. The first approach adapts the serval instrument (Rigotti and Pitt, 1992; Donaldson and Runciman, 1995; Cuthbert, 1996a, 1996b; Owlia and Aspinwall, 1996; Oldfield and Baron, 2000; O'Neill and Palmer, 2001). The second uses methods for assessing the quality of teaching and learning (Entwistle and Tait, 1990; Ramsden, 1991; Marsh and Roche, 1993). The third uses methods for assessing the quality of the total student experience (Harvey et al., 1992b; Roberts and Higgins, 1992; Hill, 1995; Aldridge and Rowley, 1998; Gaell, 2000; Watson et al., 2002; Wiers-Jenssen et al., 2002). In the studies which applied servqual there is a need in the amendment of the questionnaire, and currently there is no consensus existing about the dimensions of service quality or the significance of each of the dimension in the context of higher education con. Tan (1986) differentiated three types of studies: reputational (subject evaluations from 'experts'), objective indicator and quantitative correlating studies after conducting a thorough review of the assessment methods which are normally used for assessing teaching quality in US higher education. He concluded that: the best way to measure quality is by the use of 
multiple variables. It seems he gained little success as the biggest problem seem to lie in the fact there is very little theory available for guiding the researchers in their selection of the best combination of variables for measure quality (Tan, 1986).

This has been still the case even today as the majority of universities tend to use different variables, questions and evaluation methods. Many of these different variables, questions and evaluation methods are developed internally without considering of reliability or validity of variables and evaluation methods at hand (Ramsden, 1991; Cuthbert, 1996a; Rowley, 1996, 1997; Oldfield and Baron, 2000). The available literature on student learning exposes various well-validated questionnaires that can highlight the important dimensions of service quality in higher education (Hattie and Watkins, 1988; Entwistle and Tait, 1990; Ramsden, 1991; Marsh and Roche, 1993; Pike, 1993; Cuthbert, 1996a; Rowley, 1996). Ramsden's (1991) Course Experience Questionnaire, and Marsh and Roche's (1993) Students Evaluation of Educational Quality instrument are the most widely reported, accepted and applied methods focusing on the assessment of teaching and learning. Both of above methods are also widely criticized for only focusing on the teaching and learning experience to assess quality and so neglect the wider other student experiences as these models do not incorporate other important aspects of student experience such as the accommodation situation and on campus social life. Various higher education institutions tend to evaluate other aspects of the student life beyond the quality of teaching and learning (Roberts and Higgins, 1992; Hill, 1995; Harvey et al., 1997; Aldridge and Rowley, 1998). So we can accept the fact that the service-quality literature does not signal towards a general agreement in terms of the dimensions or measurement approach to assess quality in higher education.

In summary, recent studies (Oldfield and Baron, 2000; O’Neill and Palmer, 2001) have started exploring the value of applying service-marketing concepts and models to assess the quality in higher education sector. Some other studies try to apply various concepts from the educational literature and considered the quality of teaching and learning or the quality of total student experience as valid. As Wiers-Jenssen et al. (2000) state: student satisfaction concepts and approaches might be tools to build a bridge between more traditional and academic views for improving higher education, and more market-orientated perspectives. Most of the questions still remain unanswered. Which of the quality dimensions tend to be most important for postgraduate, part-time students? Whether researchers should measure expectations or performance alone? Whether researchers must be focusing on the teaching and learning experience or quality of total student experience? What kind of effect the highly interactive and longitudinal nature of the service experience in higher education has on all the earlier questions? Major opportunity still exists for deepening our understanding, and eventually informing improvements in practice, with the help of application of both service quality and educational concepts.

\subsection{Students' Satisfaction in Higher Education}

According to Bateson and Hoffman (1999), most of the experts agree and consider the customer satisfaction as a short term transaction specific measure while that consider service quality as an attitude that has formed over a long term evaluation of performance. Elliott and Healy (2001) have defined student satisfaction as short-term attitude that results from evaluating the student's educational experience. Two terms are not much different because the student can be regarded just another type of customer consuming education service and therefore almost all of the literature on service marketing can be applied. Experts generally agree that on a relationship between service quality and customer satisfaction but the disagreement is on the unclear nature and direction of this relationship as some researchers like Parasuraman et al. (1985) and Cronin and Taylor, (1992) have regarded service quality before customer satisfaction. On the other hand, according to Bitner (1990) service quality follows customer satisfaction. Some new studies in this area also supporting the view of service quality leading to customer satisfaction. According to a study done by Sulieman, (2013) on Jordanian banks exhibits that the five dimensions of service quality under study have a direct effect on customer satisfaction level. Other studies as one conducted in United Arab Emirates on branch campuses of some international universities revealed that only qualified lecturers, technology and other resources affect student satisfaction directly (Wilkins and Balakrishnan, 2013).

As the expectations seem to determine the outcome of satisfaction, some emphasis placed to understand the formation of expectations was studies by Zeithaml et al. (1985) who suggests that word-of-mouth, personal needs, communications, past experience of the service, price and external communications can have an influence on the consumer's expectations. The main objective of this kind of study is to help in establishing the realistic expectations so that consumers do not feel dissatisfied from the service quality (Berry et al. 1985; King 1985). However, levels of student satisfaction vary with nationalities and programs. The researchers explain that this difference could be due to difference in cultures and backgrounds that different students come from. Therefore, they recommend further research in other parts of the world as generalization of their conclusions could not be right step in this case. In view of the cultural and environmental differences that exist between China as compared to the other countries where these studies were carried out it was the researcher's view that this study be carried out to find out if service quality offered by Chinese universities has an effect on student satisfaction 
and whether there are some comparative differences among university students of Chinese universities with other world renowned universities.

\section{Methodology}

There are various studies that intended to identify higher educational service quality (HESQUAL) dimensions by using an exploratory phase consisting of qualitative research methods instead of just building on the generic SERVQUAL framework. An important issue which is worthy of consideration is that most of the models including and based on SERVQUAL model only take into account the functional quality and tend to neglect the technical quality aspect in service quality (Kang, 2006). The extant literature suggests that this is the prevalent case in higher education context too apart from few research exceptions such as Holdford and Reinders (2001), Chong and Ahmed (2012) and Clemes et al. (2013). A holistic approach is adopted in this research where five primary dimensions of HESQUAL have been identified from the extensive literature review conducted and qualitative data collection in the form of interviews and focus groups with students and academics. These five determinants included administrative quality, physical environment quality, core educational quality, support facilities quality and transformative quality along with overall satisfaction level of students. As mentioned earlier, this study used mixed model approach incorporating both qualitative and quantitative aspects of research. A pilot study was first conducted in order to evaluate the factors associated with or affecting service quality in an educational setting. For this, various semi-structured questionnaires were developed to be filled by university students, faculty and other administrative authorities. Responses from these questionnaires, personal interviews with students and other academic staff and group discussions enabled us to finalize upon the factors influencing the service quality of higher education institutions in China through a rigorous process in a cross sectional study.

\subsection{Study Design}

Five primary dimensions of HESQUAL have been identified from the extensive literature review conducted and qualitative data collection in the form of interviews and focus groups with students and academics. Thus administrative quality, physical environment quality, core educational quality, support facilities quality and transformative quality were considered as the independent determinants to evaluate our dependent variable of overall students' satisfaction in China. Quality of education in Chinese universities was found on the basis of students' satisfaction on above five service factors in the universities along with sixth dependent factor of overall students' satisfaction apart from their overall satisfaction on the accumulated service quality of these factors in the universities. Harvey and Green (1993) considered education not only being an instrument of presenting a service for a customer but rather they regarded education as continuous process to transform the participant (student). This view has also been strongly supported by empirical studies conducted by other scholars such as Lomas (2007), Watty (2005) and Zachariah (2007) who regraded this as the preferred view of educational leaders, employers, academics and students. Harvey and Knight (1996) recommended that quality education helps enabling transformation in the students and thus improving them. Thus this study seeks integrating this notion of quality for future measurement of service quality through developing and integrating a new determinant into the existing scale to measure the students' perception of transformative quality. The appropriateness of a hierarchical model was also further strengthened. The next phase of the research is to test for potential sub-dimensions through exploratory factor analysis (EFA) and also test for the validity and reliability of the measurement scales.

\subsection{Sampling Techniques}

universities based on the quality of five factors, the sample population comprised of current undergraduate and graduate students in Chinese universities. To ensure a proper sample size, Cochran's formula for sample size of an infinite population was used as given below (Cochran, 1977).

$$
n_{v}=\frac{Z^{2} \mathrm{pq}}{e^{2}}
$$

where $\mathrm{e}$ is the desired level of precision (i.e. the margin of error), $\mathrm{p}$ is the (estimated) proportion of the population which has the attribute in question, and $\mathrm{q}$ is $1-\mathrm{p}$. The main reason behind using above formula for sample size was that we could not get the definite population of Chinese students in Chinese universities and this number is quite high so it was better to utilize Cochran's formula for indefinite population according to which the sample size for an indefinite population must be higher than 384 and to be on the safe side we used a sample of 500 students spread across five Chinese universities in five different cities namely Shanghai Jiaotong University in Shanghai, China University of Communication in Beijing, Zhejiang University in Hangzhou, Huazhog University of Science and technology in Wuhan and Xian Jiatong University in Xian. 


\subsection{Variables for Satisfaction}

Satisfaction has always been attached to service quality and is made of a behavioral dimension which develops due to experience and a mental dimension which develops due to work up attitude (Oliver, 1999). In this article Satisfaction construct is described as the Chinese students' feelings about the quality of different facilities and educational environment provided in Chinese universities evaluated through five kinds of quality determinants namely Administrative Quality, Physical Environment Quality, Core Educational Quality, Support Facilities Quality and Transformative Quality of higher education institutions in China.

\section{Administrative Quality}

Administrative quality of a university was based on two major factors including Attitude and Behavior of administrative staff and administrative processes. Attitude and behavior of the administrative staff was evaluated through willingness of administrative staff members to help students, ability of administrative staff members to solve students' problems, politeness of administrative staff and behavior of administrative staff members imparting confidence in students. Administrative processes were evaluated through well standardized administrative processes due to which there is not much bureaucracy and useless difficulties, clear and wellstructured administrative procedures so that service delivery time is at minimum and transparency of official procedures and regulations. On the basis of above constructs we tried to test following hypothesis;

H1. Better administrative quality based on better attitude and behavior of administrative staff and other administrative processes in higher education institutions in China tend to increase students' satisfaction.

\section{Physical Environment Quality}

Physical environment quality of a university primarily depended on three factors including support infrastructure, learning settings and general infrastructure. Support infrastructure of the Chinese universities was evaluated through availability of adequate cafeteria infrastructure, availability of adequate library infrastructure, availability of adequate recreational infrastructure and availability of adequate sports infrastructure. Learning settings were evaluated through having adequate lecture rooms, having quiet places to study within campus and availability of adequate teaching tools and equipment e.g. projector, white boards. General infrastructure was evaluated by having favorable ambient conditions (ventilation, noise, odor, etc.) prevailing within the campus, safety on campus and appearance of buildings and grounds.

H2. Better physical environment quality based on better support infrastructure, learning settings and general infrastructure in higher education institutions in China tend to increase students' satisfaction.

\section{Core Educational Quality}

Core educational quality of a university had four constructs namely attitude and behavior of the lecturers, curriculum of university, pedagogy of university and competence of lecturers. Furthermore, attitude and behavior of the teaching staff was evaluated through their understanding of students' needs, their personal attention to students, their availability to guide and advise students, prevalence of a culture of sharing and collaboration among lecturers, their behavior of instilling confidence in students and lecturers appearing to have students' best interest at heart. Curriculum was evaluated through how much clearly defined course content and course objectives are, how much useful module content and design are to cater for the personal needs of students, how much challenging academic standards of programs are to ensure students' overall development and relevance of course content to the future/current job of students. Pedagogy was evaluated with students' views about use of multimedia in teaching (e.g. use of overhead projector, power-point presentations, active participation of students in their learning process, provision of regular feedback to students with respect to their academic performance and how much well-designed examinations and continuous assignment are to promote the enhancement of knowledge skills. Competence of lecturers was evaluated through the theoretical knowledge, qualifications and practical knowledge of lecturers, communication skills of lecturers and how much up-to-date lecturers are in their area of expertise.

H3. Better core educational quality based on better attitude and behavior of the lecturers, curriculum of university, pedagogy of university and competence of lecturers in higher education institutions in China tend to increase students' satisfaction.

\section{Support Facilities Quality}

Support facilities quality of the university was evaluated through students' opinions about reasonable pricing and quality of food and refreshments on campus, availability of adequate IT facilities, availability and adequacy of photocopy and printing facilities, availability of transport facilities, amount of opportunity for sports and recreational facilities, availability and adequacy of extracurricular and activities including those through 
clubs and societies

H4. Better support facilities in higher education institutions in China tend to increase students' satisfaction.

\section{Transformative Quality}

Transformative quality of higher education institutions in China was evaluated with the help of students' views about how much an institution was successful in enabling students to be emotionally stable, increasing the self-confidence of students, development of students' critical thinking, increasing the selfawareness of students, development of problem-solving skills with respect to their field of study, enabling students to transcend their prejudices, acquiring adequate knowledge and skills to perform future job, and increasing the knowledge, abilities and skills of students.

H5. Better transformative quality in higher education institutions in China tends to increase students' satisfaction.

\subsection{Data Collection}

Quantitative data was collected using self-administered questionnaire. All the surveys were personally administered. As Cochran's formula of sample size for indefinite population was used according to which the sample size for an indefinite population must be higher than 384 and to be on the safe side we used a sample of students spread across five Chinese universities in five different cities namely Shanghai Jiaotong University in Shanghai, China University of Communication in Beijing, Zhejiang University in Hangzhou, Huazhog University of Science and technology in Wuhan and Xian Jiatong University in Xian.

\subsection{Data Analysis}

Before data feeding, questionnaires filled by students from five Chinese universities went through a thorough review. Then data was fed into IBM SPSS 21.0 with the help of an experienced data clerk under the direct supervision of the lead researcher. Data cleaning and data analysis was conducted by the researcher after completion of data cleaning. Each of the variables were checked for coherence and consistence, missing values were checked and compared against the questionnaires during the data cleaning process. All the determinants were checked to find out the statistical validity \& reliability using Cronbach-alpha and found to have a result of 0.8 and beyond. Each of the five independent variables including administrative quality, physical environment quality, core educational quality, support facilities quality and transformative quality was checked for multicollinearity through correlations and it was found that each independent variable was non-multi collinear to rest of the independent variables. Finally, data was analyzed mainly using descriptive statistics and students' overall satisfaction was made using Exploratory Factor Analysis first to validate all the determinants of our research and then through multiple regression analysis to check all hypothesis.

\section{Results and Discussion}

\subsection{Data Analysis}

Descriptive analysis of the respondents is given in Table 1 below which shows the elaborate demographic characteristics of the students surveyed.

Table 1: Demographic Data of Students

\begin{tabular}{|c|c|c|}
\hline Demographic Objects & Valid Items & Percent \% \\
\hline \multirow{6}{*}{ Age } & $18-21$ & 61.8 \\
\hline & $22-24$ & 29.8 \\
\hline & $25-27$ & 1.8 \\
\hline & $28-31$ & 4 \\
\hline & $32-34$ & 0.8 \\
\hline & $>=35$ & 1.8 \\
\hline \multirow{3}{*}{ Gender } & Male & 46 \\
\hline & Female & 53.4 \\
\hline & Others & 0.6 \\
\hline \multirow{4}{*}{ Highest Degree Completed } & Higher Secondary Education (College & 41 \\
\hline & Undergraduate & 50.6 \\
\hline & Master & 6.8 \\
\hline & $\mathrm{PhD}$ & 1.6 \\
\hline \multirow{4}{*}{ Current Degree } & Diploma & 1.2 \\
\hline & Undergraduate & 76.8 \\
\hline & Master & 14.8 \\
\hline & $\mathrm{PhD}$ & 7.2 \\
\hline \multirow{4}{*}{ Current Year of Study } & First Year (Freshman) & 27.6 \\
\hline & Second Year (Sophomore) & 16.2 \\
\hline & Third Year (Junior) & 26.6 \\
\hline & Fourth Year (Senior) & 29.6 \\
\hline
\end{tabular}


All the six determinants were checked through Exploratory Factor Analysis using extraction method of principle component analysis and rotation method of Varimax rotation with Kaiser Normalization (Kaiser, 1958). Cronbach's alpha was calculated for all the determinants to find out their reliability along with a test was also run for checking the multi collinearity among the independent variables and none of the independent variables were multi collinear. Then all the factors were loaded on to the specified determinants along with their variance percentage, eigenvalues, cumulative variance and Cronbach's alphas as given below in Table 2 .

Table 2: Exploratory Factor Analysis

\begin{tabular}{|c|c|c|c|c|c|c|}
\hline Meas urement Items & Factor 1 & Factor 2 & Factor 3 & Factor 4 & Factor 5 & Factor 6 \\
\hline \multicolumn{7}{|l|}{ Adminis trative Quality } \\
\hline $\begin{array}{l}\text { - Willingness of administrative staff } \\
\text { members to help students }\end{array}$ & 0.812 & & & & & \\
\hline $\begin{array}{l}\text { - Ability of administrative staff members to } \\
\text { solve students' problems }\end{array}$ & 0.816 & & & & & \\
\hline - Politeness of administrative staff & 0.803 & & & & & \\
\hline $\begin{array}{l}\text { - Behavior of administrative staff members } \\
\text { in imparting confidence in students }\end{array}$ & 0.783 & & & & & \\
\hline $\begin{array}{l}\text { - Well standardized administrative processes } \\
\text { due to which there is not much bureaucracy } \\
\text { and useless difficulties }\end{array}$ & 0.77 & & & & & \\
\hline $\begin{array}{l}\text { - Clear and well-structured administrative } \\
\text { procedures so that service delivery time is at } \\
\text { minimum }\end{array}$ & 0.785 & & & & & \\
\hline $\begin{array}{l}\text { - Transparency of official procedures and } \\
\text { regulations }\end{array}$ & 0.837 & & & & & \\
\hline \multicolumn{7}{|l|}{ Physical Environment Quality } \\
\hline $\begin{array}{l}\text { - Availability of adequate cafeteria } \\
\text { infrastructure }\end{array}$ & & 0.643 & & & & \\
\hline $\begin{array}{l}\text { - Availability of adequate library } \\
\text { infrastructure }\end{array}$ & & 0.668 & & & & \\
\hline $\begin{array}{l}\text { - Availability of adequate sports } \\
\text { infrastructure }\end{array}$ & & 0.806 & & & & \\
\hline - Having adequate lecture rooms & & 0.73 & & & & \\
\hline - Having adequate lecture rooms & & 0.846 & & & & \\
\hline $\begin{array}{l}\text { - Availability of adequate teaching tools and } \\
\text { equipment (e.g. Projector, White boards) }\end{array}$ & & 0.849 & & & & \\
\hline $\begin{array}{l}\text { - Favorable ambient conditions (ventilation, } \\
\text { noise, odor, etc.) prevailing within the } \\
\text { campus }\end{array}$ & & 0.809 & & & & \\
\hline - Safety on campus & & 0.62 & & & & \\
\hline - Appearance of buildings and grounds & & 0.707 & & & & \\
\hline \multicolumn{7}{|l|}{ Core Educational Quality } \\
\hline - Lecturers understanding of students' needs & & & 0.652 & & & \\
\hline - Lectures' personal attention to students & & & 0.843 & & & \\
\hline $\begin{array}{l}\text { - Availability of lecturers to guide and advise } \\
\text { students }\end{array}$ & & & 0.75 & & & \\
\hline $\begin{array}{l}\text { - Prevalence of a culture of sharing and } \\
\text { collaboration among lecturers }\end{array}$ & & & 0.743 & & & \\
\hline $\begin{array}{l}\text { - Behavior of lecturers instilling confidence } \\
\text { in students }\end{array}$ & & & 0.729 & & & \\
\hline $\begin{array}{l}\text { - Lecturers appearing to have students' best } \\
\text { interest at heart }\end{array}$ & & & 0.817 & & & \\
\hline $\begin{array}{l}\text { - Clearly defined course content and course } \\
\text { objectives }\end{array}$ & & & 0.612 & & & \\
\hline $\begin{array}{l}\text { - Useful module content and design to cater } \\
\text { for the personal needs of students }\end{array}$ & & & 0.562 & & & \\
\hline $\begin{array}{l}\text { - Challenging academic standards of } \\
\text { programs to ensure students' overall } \\
\text { development }\end{array}$ & & & 0.654 & & & \\
\hline $\begin{array}{l}\text { - Relevance of course content to the } \\
\text { future/current job of students }\end{array}$ & & & 0.546 & & & \\
\hline $\begin{array}{l}\text { - Use of multimedia in teaching (e.g. use of } \\
\text { overhead projector, power-point } \\
\text { presentations) }\end{array}$ & & & 0.748 & & & \\
\hline
\end{tabular}


- Active participation of students in their learning process

- Provision of regular feedback to students with respect to their academic performance

- Well-designed examinations and continuous assignment to promote the enhancement of knowledge skills

- Theoretical knowledge, qualifications and practical knowledge of lecturers

- Communication skills of lecturers

- Up-to-date lecturers in their area of expertise

Support Facilities Quality

- Reasonable pricing and quality of food and refreshments on campus

- Availability of adequate IT facilities

- Availability and adequacy of photocopy

and printing facilities

- Availability of transport facilities

- Amount of opportunity for sports and recreational facilities

- Availability and adequacy of extracurricular activities

- Availability of other activities including clubs and societies.

Transformative Quality

- Enabling students to be emotionally stab

- Increase in self-confidence of students

- Development in students' critical thinking

- Increase in self-awareness of students

- Development of problem-solving skills with respect to their field of study

- Enabling students to transcend their prejudices

- Acquiring adequate knowledge and skills to perform future job

- Increase in knowledge, abilities and skills of students

\begin{tabular}{|l|l|}
\hline+2 & \\
\hline & \\
\hline & \\
\hline & \\
\hline & \\
\hline & \\
\hline & \\
\hline & \\
\hline & \\
\hline
\end{tabular}

\begin{tabular}{|r|}
\hline 0.65 \\
\hline 0.722 \\
\hline 0.678 \\
\hline 0.75 \\
\hline 0.782 \\
\hline 0.777 \\
\hline
\end{tabular}

0.651

0.722

0.678

0.75

0.782

0.777

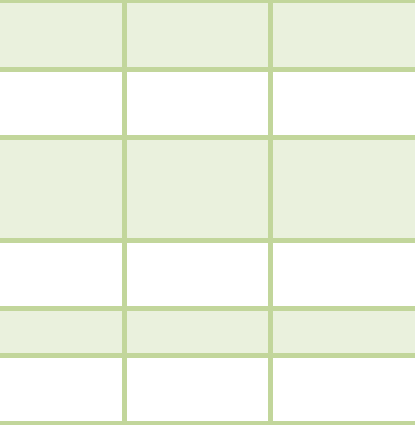

\begin{tabular}{|l|r|r|r|r|}
\hline & & 0.78 & \\
\hline & & & 0.749 & \\
\hline & & 0.84 & \\
\hline & & 0.756 & \\
\hline & & & 0.768 & \\
\hline & & & 0.846 & \\
\hline & & & 0.855 & \\
\hline
\end{tabular}

\begin{tabular}{|l|l|l|r|}
\hline & & & 0.671 \\
\hline & & & 0.768 \\
\hline
\end{tabular}

Overall Satisfaction

- How much satisfied are you with the attitude and behavior of the administrative staff of the university?

- How much satisfied are you with the

administrative processes of the university?

- How much satisfied are you with the

support infrastructure of the university?

- How much satisfied are you with the

learning settings of the university?

- How much satisfied are you with the general infrastructure of the university?

- How much satisfied are you with the

attitude and behavior of the lecturers of the

university?

- How much satisfied are you with the

curriculum of the university? 


\begin{tabular}{|c|c|c|c|c|c|c|}
\hline $\begin{array}{l}\text { - How much satisfied are you with the } \\
\text { pedagogy of the university? }\end{array}$ & & & & & & 0.739 \\
\hline $\begin{array}{l}\text { - How much satisfied are you with the } \\
\text { competence of the lecturers of the } \\
\text { university? }\end{array}$ & & & & & & 0.756 \\
\hline $\begin{array}{l}\text { - How much satisfied are you with the } \\
\text { support facilities quality of the university? }\end{array}$ & & & & & & 0.665 \\
\hline $\begin{array}{l}\text { How much satisfied are you with the } \\
\text { transformative quality of the university? }\end{array}$ & & & & & & 0.785 \\
\hline Eigenvalues & 4.836 & 5.667 & 9.958 & 4.18 & 5.741 & 5.464 \\
\hline Percentage of Variance & 69.08 & 56.67 & 58.574 & 59.713 & 71.765 & 49.671 \\
\hline Cumulative Variance & 78.296 & 65.452 & 65.632 & 72.832 & 78.443 & 59.509 \\
\hline Cronbach's alpha & 0.924 & 0.912 & 0.955 & 0.887 & 0.943 & 0.898 \\
\hline
\end{tabular}

\subsection{Hypotheses H1-H5: Students' satisfaction vs. Determinants of Satisfaction}

To test each hypothesis separately through multiple regression analysis; we used regression model separately for each and every independent variable namely administrative quality, physical environment quality, core educational quality, support facilities quality and transformative quality of the university with respect to overall students' satisfaction. Outcomes of multiple linear regressions for hypotheses $\mathrm{H} 1 \rightarrow \mathrm{H} 5$ are given below in Table 3 along with standardized regression's coefficient of every predictor i.e. $\beta$ along with $\mathrm{R}^{2}$ and $\mathrm{F}$ of students' overall satisfaction (for all of the predictors in this linear regression analysis).

Table 3: Results of Multiple Regression Analysis

\begin{tabular}{|c|c|}
\hline Independent & Dependent (Students' Satisfaction) \\
\hline \multirow{3}{*}{ All Determinants } & Overall Satisfaction \\
\hline & $\mathrm{R}^{2}=.959$ \\
\hline & $\mathrm{F}=132.368$ \\
\hline \multirow{2}{*}{ Administrative Quality } & $\beta=.079$ \\
\hline & $\mathrm{t}=1.856$ \\
\hline \multirow{2}{*}{ Physical Environment Quality } & $\beta=.116$ \\
\hline & $\mathrm{t}=2.299$ \\
\hline \multirow{2}{*}{ Core Educational Quality } & $\beta=.189$ \\
\hline & $\mathrm{t}=3.014$ \\
\hline \multirow{2}{*}{ Support Facilities Quality } & $\beta=.272$ \\
\hline & $t=4.879$ \\
\hline \multirow{2}{*}{ Transformative Quality } & $\beta=.191$ \\
\hline & $\mathrm{t}=2.891$ \\
\hline
\end{tabular}

Results shown in the above table as a result of multiple regression analysis show that physical environment quality, core educational quality, support facilities quality and transformative quality of a university are positively and significantly correlated with the overall satisfaction of students in Chinese universities having $\mathrm{p}<0.05$ eventually supporting $\mathrm{H} 2-\mathrm{H} 5$ while administrative quality of a university in terms of attitude and behavior of administrative staff and other administrative processes do not seem to be significantly affecting the overall satisfaction of Chinese students as $p>0.05$ in this case in turn rejecting $\mathrm{H} 1$ which can be elaborated that better administrative quality of universities in China does not seem to affect the overall satisfaction of the Chinese students. This can be justified as most of the students do not have frequent interactions with administrative staff and administrative processes of a university due to which this determinant does not seem to have much influence on their overall satisfaction level.

\section{Conclusion and Recommendations}

Main objective of this research was to first identify certain parameters through literature review which are responsible for improving students overall satisfaction as a whole due to increased emphasis on students' performance in university and at workplace on their overall satisfaction of university setting all over the world nowadays and then test those parameters in Chinese universities as cultural differences can change personal preferences and parametric conclusions on the satisfaction by Chinese students. 5 key factors were explored and validated here along with their relation with overall satisfaction of Chinese students that included Administrative Quality of a university based on attitude and behavior of administrative staff and administrative processes, 
Physical Environment Quality based on support infrastructure, learning settings and general infrastructure, Core Educational Quality based on attitude and behavior of lecturers, curriculum, pedagogy and competence of lecturers, Support Facilities Quality and Transformative Quality. All five determinants were validated through exploratory factor analysis and then each of the determinants was separately tested for its contribution towards overall satisfactions of students in Chinese higher institutions that exhibited that only administrative quality does not significantly affect satisfaction level of students variably due to their less interaction with administrative staff and process of the university. Thus future researchers, academicians and students can fully benefit from this research in terms of improving the research models, improving learning setting in China for students along with Chinese students' preferences in terms of learning environment and quality they expect in a higher institution. As this research is limited in terms of its scope as only 5 universities in five different cities of Peoples republic China were examined so there is still need to investigate this further in terms of variables exploration, diversification and an upsurge in sample size to better understand the real determinants of all the Chinese students studying in higher education institutions in China.

\section{References}

Abdullah, F. (2005), 'HEdPERF versus SERVPERF: The quest for ideal measuring Instrument of service quality in higher education sector', Quality Assurance in Education, Vol.13, No.4, pp.305-328.

Abdullah, F. (2006a), 'Measuring Service Quality in Higher Education: HEdPERF versus SERVPERF', Marketing intelligence and Planning, Vol.24, No.1, pp.31-47.

Aldridge, S. \& Rowley, J., (1998), 'Measuring customer satisfaction in higher education', Quality Assurance in Education, 6(4), pp. 197-204.

Awan, M. U., Azam, S. and Asif, M. (2008), 'Library Services Quality Assessment', Journal of Quality and Technology Management, Vol.4, No.1, pp.51-64.

Barnett, R., (1994), 'The idea of quality: voicing the educational', in DOHERTY, G.D. (Ed.) Developing Quality Systems in Higher Education (London, Routledge).

Bateson, J. E. G., \& Hoffman, K. D. (1999). Managing services marketing (4th ed.). Fort Worth: The Dryden Press.

Bitner, M. J. (1990). "Evaluating Service Encounters: The Effects of Physical Surroundings and Employee Responses”. 54(2), 69-82.

Carrillat, F. A., Jaramillo, F., \& Mulki, J. P. (2007)." The validity of the SERVQUAL and SERVPERF Scales: A meta-analytic view of 17 years of research across five continents". International Journal of Service Industry Management, 18(5), 472-490.

Chong, Y.S. and Ahmed, P.K. (2012), “An empirical investigation of students' motivational impact upon university service quality perception: a self- determination perspective”, Quality in Higher Education, Vol. 18 No. 1, pp. 37-41.

Clemes, M.D., Cohen, D.A. and Wang, Y. (2013), “Understanding Chinese university students' experiences: an empirical analysis", Asia Pacific Journal of Marketing and Logistics, Vol. 25 No. 3, pp. 391-427.

Cochran, W.G. (1977), Sampling techniques ( ${ }^{\text {rd }}$ Eed.). New York: John Wiley \& Sons.

Cronin, J. \& Taylor, S., (1992), 'Measuring service quality: a re-examination and extension', Journal of Marketing, 56, pp. 55-68.

Cuthbert, P., (1996a), 'Managing service quality in HE: is SERVQUAL the answer?' Part 1, Managing Service Quality, 6(2), pp. 11-16.

Cuthbert, P., (1996b), 'Managing service quality in HE: is SERVQUAL the answer?' Part 2, Managing Service Quality, 6(3), pp. 31-35.

Donaldson, B. \& Runciman, F., (1995), 'Service quality in further education: an insight into management perceptions of service quality and those of the actual service provider', Journal of Marketing Management, 11, pp. 243-256.

Elliott, K. M., \& Healy, M. A. (2001). "Key Factors Influencing Student Satisfaction Related to Recruitment and Retention”. Journal of Marketing for Higher Education, 10(4), 1-11. doi:10.1300/J050v10n04_01

Entwistle, N. \& Tait, H., (1990), 'Approaches to learning evaluation of teaching and preferences for contrasting academic environments', Higher Education, 9, pp. 169-194.

Gaell, V., (2000), 'The expectations and experience of first-year students at City University of Hong Kong', Quality in Higher Education, 6, pp. 77-89.

Grapentine, T., (1999), 'The history and future of service quality assessment', Marketing Research, Winter/Spring, pp. 5-20.

Gronroos, C., (1984), 'A service quality model and its marketing implications', European Journal of Marketing, 18(4), pp. 36-44.

Harvey, L. \& Green, D., (1993), 'Defining quality', Assessment and Evaluation in Higher Education, 18(1), pp. 9-34. 
Harvey, L., Burrows, A. \& Green, D., (1992a), Criteria of Quality (Birmingham, UCE).

Harvey, L., Burrows, A. \& Green, D., (1992b), Total Student Experience: a first report of the QHE National Survey of Staff and Students' Views of the Important Criteria for Assessing the Quality of Higher Education (Birmingham, QHE).

Harvey, L. and Knight, P. (1996), Transforming Higher Education, Society for Research into Higher Education, London.

Hattie, J. \& Watkins, D., (1988), 'Preferred classroom environment and approach to learning', British Journal of Educational Psychology, 58, pp. 345-349.

Hill. F. M. (1995), 'Managing service quality in higher education: the role of the student as primary consumer', Quality Assurance in Education, Vol. 3, No.3, pg.1-11.

Holdford, D. and Reinders, T.P. (2001), "Development of an instrument to assess student perceptions of the quality of pharmaceutical education”, American Journal of Pharmaceutical Education, Vol. 65 No. 2, pp. 125-131.

King, C.A. (1985), "Service Quality is Different", Quality Progress, June, pp.14-18

Kaiser, H. F. (1958) The varimax criterion for analytic rotation in factor analysis. Psychometrika 23, 187-200.

La, K. V., Kandampully, J. (2004), 'Market oriented learning and customer value enhancement through service recovery management', Managing Service Quality, Vol.14, No.5, pp.390-401.

Lomas, L. (2007), “Zen, motorcycle maintenance and quality in higher education”, Quality Assurance in Education, Vol. 15 No. 4, pp. 402-412.

Malik M.E (2010). "The Impact of Service Quality on Students' Satisfaction in Higher Education Institutes of Punjab”, University of the Punjab, Pakistan; Rizwan Qaiser Danish

Marsh, H. \& Roche, L, (1993), 'The use of students' evaluations and an individually structured intervention to enhance university teaching effectiveness', American Educational Research Journal, 30, pp. 217-251.

Mulu N. K., (2012). "Quality and quality assurance in Ethiopian higher education: critical issues and practical implications", dissertation to obtain the degree of doctor at the university of Twente, on the authority of the rector magnificus, prof. Dr. h. Brinksma,

National Bureau of Statistics of China. http://data.stats.gov.cn/workspace/index;jsessionid $=C 781 D 208 E 25 C 79 B 326 B D B 5 A 26 F 52 C E 16 ? \mathrm{~m}=h$ gnd

Oldfield, B. \& Baron, S., (2000), 'Student perceptions of service quality in a UK university business and management faculty', Quality Assurance in Education, 8(2), pp. 85-95.

Oliver, R. (1999). Whence consumer loyalty? Journal of Marketing, 63, 33-44.

O’Neill, M. \& Palmer, A., (2001), 'Survey timing and consumer perceptions of service quality: an overview of empirical evidence', Managing Service Quality, 11(3), pp. 182-190.

Owlia, M. S., \& Aspinwall, E. M. (1996). A framework for the dimensions of quality in higher education. Quality Assurance in Education, 4(2), 12-20.

Pan and Xiao (2008). "Review on the Development and Reform of Higher Education in China for the Last Thirty Years (改革开放 30 年中国高等教育发展经验专题研究: 1978-2008)”. Journal of Higher Education, Vol. 29 No. 10. Educational Science Publishing House. 2008.

Parasuraman, A., Zeithaml, V. and Berry, L.L., (1985), "A conceptual model of service quality and its implications for future research", Journal of Marketing, Vol. 49, autumn, pp. 41-50

Parasuraman, A., Zeithaml, V. and Berry, L.L., (1988), "SERVQUAL: a multiple-item scale for measuring consumer perceptions of service quality”, Journal of Retailing, Vol. 64, spring, pp. 12-40.

Parves Sultan, Ho Yin Wong, (2012) "Service quality in a higher education context: an integrated model", Asia Pacific Journal of Marketing and Logistics, Vol. 24 Issue: 5, pp.755-784, https://doi.org/10.1108/13555851211278196

Pike, G., (1993), 'the relationship between perceived learning and satisfaction with college, Research in Higher Education, 34(1), pp. 23-40.

Ramsden, P., (1991), 'Performance indicator of teaching quality in higher education: the course experience questionnaire', Studies in Higher Education, 16(2), pp. 129-150.

Reynolds, P.A., (1990), 'Is an external examiner system an adequate guarantee of academic standards?', in LODER, C.P.J. (Ed.) Quality Assurance and Accountability in Higher Education (London, Kogan Page).

Rigotti, S. \& Pitt, L., (1992), 'SERVQUAL as a measuring instrument for service provider gaps in business schools', Management Research News, 15(3), pp. 9-17.

Robinson, S., (1999), 'Measuring service quality: current thinking and future requirements', Marketing Intelligence and Planning, 17(1), pp. 21-32.

Roberts, D. \& Higgins, T., (1992), Higher Education: the student experience. The Findings of a Research Programme into Student Decision-Making and Consumer Satisfaction (Leeds, Heist). 
Rowley, J., (1997), 'Beyond service quality dimensions in higher education and towards a service contract', Quality Assurance in Education, 5(1), pp. 7-14.

Rowley, J., (1996), 'Measuring quality in higher education', Quality in Higher Education, 2(3), pp. $237-255$.

Samat, N., Ramayah, T. and Saad, N. M. (2006), 'TQM practices, service quality and market orientation, some empirical evidence from developing country', Management research news, Vol.29, No.11, pp.713-728.

Sulieman, A. (2013)." Basic dimensions of the (servqual model) and its impact on the level of customer satisfaction: an empirical study of the housing bank in karak, jordan. European Scientific Journal, 9(1)". Retrieved from http:/leujournal.org/index.php/esj/article/view/690.

Tam, M., (2001), 'Measuring quality and performance in higher education', Quality in Higher Education, 7(1), pp. 47-54.

Tan, D., (1986), 'The assessment of quality in higher education: a critical review of the literature and research', Research in Higher Education, 24(3), pp. 223-265.

Ugboma, C., Ogwude, I. C., Ugboma, O. \& Nadi, K., (2007) "Service quality and Satisfaction Measurements in Nigerian Ports: An Exploration," Maritime Policy \& Management 34 (4)331-346.

Watson, S., Saldana A. \& Harvey, L., (2002), The 2002 Report on the Student Experience at UCE (Birmingham, Centre for Research into Quality, UCE).

Watty, K. (2005), “Quality in accounting education: what say the academics?”, Quality Assurance in Education, Vol. 13 No. 2, pp. 120-131.

Wiers-Jenssen, J., Stensaker, B. \& Grogard, J. (2002), 'Student satisfaction: towards an empirical deconstruction of the concept', Quality in Higher Education, 8(2), pp. 183-195.

Wilkins, S., and Balakrishnan, M. S. (2013). "Assessing student satisfaction in transnational higher education". International Journal of Educational Management, 27(2), 143 - 156.

Zachariah, S. (2007), "Managing quality in higher education: a stakeholder perspective”, PhD thesis, University of Leicester.

Zeithaml, V., Parasuraman, A. \& Berry, L., (1985), 'Problems and strategies in services marketing', Journal of Marketing, 49(1), pp. 33-46. 